\title{
The geographical and social distribution of native languages in central Ukraine
}

\begin{abstract}
By declaring a language as their native language or mother tongue, people carry out an act of identification with this language, and via this language with people and ideas to whom they assign the same language. This comes to the fore especially when external conflicts are transferred to the linguistic constellation. This is the case in Ukraine, where three languages / codes are at the disposal: the state's official language Ukrainian, but also Russian, and "suržyk", a widespread form of speech containing both Ukrainian and Russian elements. Based on a survey from 2014 in the central regions of Ukraine, this article examines which of these languages / codes are chosen as a native language and how this choice is connected with more objective aspects of language use. By means of generative additive mixed-effects modeling, it will be shown how this choice varies both socially and geographically.
\end{abstract}

K e y w ord s : Ukrainian; Russian; suržyk; mother tongue; native language; language and society; symbolic aspects of language; multilingualism; language attitudes

\section{Introduction}

The concept native language (or mother tongue) is a conglomerate of various factors (Skutnabb-Kangas \& Phillipson 1989; O’Rourke \& Ramallo 2011). The most prevalent association may be the first acquired language, connected with aspects like childhood and family. It is also linked to aspects like profi- 
ciency, amount of daily use and how comfortable the speaker feels speaking in the language. Finally, it is associated with constructs a person can feel part of, like ethnic group, nation or state.

While this multi-dimensional nature of the concept may go unnoticed for some people, it becomes more potent when there is a choice between more than one language, that is for multilingual individuals and for multilingual societies. Imagine that for two persons one aspect (say: the aspect of first language) argues for language A as the native language while another aspect (for example, the language most used) argues for language B. It can well be the case, that one of these individuals calls language $\mathrm{A}$, the other language $\mathrm{B}$ his/her native language. The question is what motivates the speakers to prioritize the one aspect over the other. The importance of the aspects themselves is certainly in many cases of minor relevance to the speakers. By prioritizing one or the other, people essentially do not say that the one aspect is more important than the other for their definition of native language, but they prioritize one language over the other. Naming a language in such a way as "their" language speakers carry out an act of identification with other people or ideas to whom they assign the same language (Rampton 1990; Singh 2006). Therefore, the speakers' choice tells us about the culturally constructed identity of speakers (O’Rourke \& Ramallo 2011).

As a consequence, people may claim to have (and, one should argue, as a consequence indeed have) more than one native language, and their choice may be different in different phases of life or even in different situations. Nevertheless, the choice of a native language is certainly not completely independent from objective criteria. Although it is the speakers who choose to name a language as their native language or not, naming a language as the native language is certainly "easier" when it is also the first language, the language which is used on a daily basis and in which the speakers have the highest proficiency. It is "more difficult" when this is not the case.

When extra-linguistic conflicts are transferred into the linguistic situation, the question of the native language can be a highly-charged question. This is the case in Ukraine. After the breakdown of the Soviet Union, Ukraine experienced transition in many dimensions: not only in the political, economic and social spheres, but also in connection with the process of nation-building in what one might call the ideological sphere (Barner-Barry \& Hody 1995; Kuzio 2002; Kappeler 2011). The question of language was 
and is seen as connected with this transition. Whereas Russian was the politically and socially dominant language in Soviet times, since independence in 1991 the status of Ukrainian overall was promoted in many domains, while the role of Russian was reduced. The intensity of this "Ukrainization" differed under the different governments - from a rather careful uprating of Ukrainian under President L. Kravčuk (1991-1994), a policy of non-interference under L. Kučma (1994-2005), to a strong promotion, at least on paper, under V. Juščenko (2005-2010). The years under President V. Janukovyč (2010-2014), who in his election campaign had promised to make Russian the second state language, saw a more Russian-oriented policy with the most incisive result being a new language law in 2012 that made it possible to give Russian (and in theory any other minority language) the status of a regional official language in districts where more than $10 \%$ named it as their "native language/mother tongue". This term (ukr. ridna mova) was not defined clearly in the language law. On the one hand, it was defined as the first language a person has acquired in early childhood, on the other hand the law stated that every person has the right to decide freely which language is "used" as native language (cf. Hentschel \& Brüggemann 2015). However, nine out of 27 districts (in 13 the $10 \%$ mark was passed) made use of this possibility (Moser 2013; 2015). Soon after the "Euromaidan", the Ukrainian parliament voted to repeal this law but in face of protest both from within and from outside of the country, the interim president O. Turčynov did not sign the bill. In 2019, a new language law was adopted that prescribes the knowledge of and the use of the state language Ukrainian in many domains. This law is disputed both inside and outside Ukraine.

The speed and the success of Ukrainization was regionally different (Fournier 2002). The idea of "two Ukraines" (Riabchuk 2002) is commonplace. While the West is linguistically Ukrainian-dominated, in the South and East Russian dominates. The reason for this "division" is seen in historical aspects, in particular in historical settlement movements and in the belonging (and different duration of belonging) to different historical states and empires (i.e. to the Polish-Lithuanian Commonwealth, the Austro-Hungarian empire, the Russian empire, the Second Polish Republic, the USSR). Furthermore, it is often suggested that there are two identity models in Ukraine, one focusing on a Ukrainian national identity and emphasizing the differences to Russia, and one that consists of a feeling of an East Slavic unity, in particu- 
lar of a togetherness with Russia, in opposition to "the West" (Shulman 2004; Törnquist-Plewa 2006; Wilson 2009; Osipian \& Osipian 2012; Korostelina 2013). While the former is said to be dominant in the Western parts, the latter is attributed to the South and the East. The commitment to and the use of the Ukrainian or the Russian language have been seen as an index of these global political orientations (cf. Engelman 2001; Kulyk 2010; Zaliznjak 2012). For Ukrainian-speaking Ukrainians, a "Western" orientation and an advocacy of national independence is believed to be more widespread than for Russianspeaking Ukrainians.

In reality, the picture is more complex. First, in light of the distribution of the languages in the country, the markedness constellation differs over the country. The use of Ukrainian in Eastern parts of the country is marked, and often an act of political identification. In the Western parts this need not be the case. Secondly, one problem with the notion of the two Ukraines is that "nobody can say where one half ends and the other begins" (Riabchuk 2002: 2). The huge central part of Ukraine is seen as a heterogeneous transition zone, each region or city with "its own peculiar combination of 'Ukrainianness' and 'Russianness', 'Europeanness' and 'Sovietism"' (Riabchuk 2002: 2). And even the most extreme "Ukrainian West" and the most extreme "Russian East" are not as monolithic as it seems at first glance, but contain traits of the "other Ukraine". Thirdly, it is not only the two standard languages that play a role in Ukraine. In daily life many people make use of a speech variety that consists of structures and elements from both languages. This Ukrainian-Russian mixed speech (in the following: URMS) called "suržyk" in the country itself - is a phenomenon which is undoubtedly widespread, but carries a stigma since it is seen as an index of low education and linguistic awareness. The term "suržyk" originally refers to mixed flour, flour of lower quality, and the phenomenon of URMS is often seen as "chaotic mixing" between Russian and Ukrainian. However, essentially URMS has to be understood as a partly stabilized variety between autochthonous dialects and the standard and thus as not very different from regiolects and urban dialects in other parts of Europe, with the specification, that the socially dominant standard has been Russian, and not Ukrainian (Hentschel 2018: 128). In opposition to the stereotype URMS is also used by well-educated people who have a high proficiency in at least one of the two standard languages 
(Hentschel \& Zeller 2017). And fourthly, there is no strict dichotomy between Russian- and Ukrainian-speaking people, because at least in the central parts of Ukraine most people make use of both languages (and of URMS) at least sometimes (Hentschel \& Taranenko 2015).

The conflict of values and political orientations in Ukraine has been sharpened in the course of the events during and after the Euromajdan in 2014. How this relates to the languages is a debated question. The Russian Federation has presented the situation in Ukraine as a language conflict, and justified the occupation of Crimea with an alleged threat to Russianspeaking people. On the other hand, some Ukrainian linguists believe that the presence of Russian in Ukraine poses a threat to Ukrainian independence and that a "Ukrainian identity" is hard to imagine for Russian-speaking individuals (for an example, see Masenko 2020). However, recent data demonstrate that in spite of the heated political debate in the eyes of both predominantly Russian- and Ukrainian-speaking Ukrainians both languages coexist rather peacefully (Zalizniak 2020). A pro-Ukrainian orientation is also widespread among predominantly Russian-speaking Ukrainians (Zeller, forthcoming). Not only are regional differences losing some of their relevance (Riabchuk 2015), the impact of linguistic orientation on political attitudes also has lost some of its importance in the course of the Euromaidan, which was supported by many primarily Russian-speaking Ukrainians (Kulyk 2016; Pop-Eleches \& Robertson 2018). Many predominantly Ukrainianspeaking Ukrainians, in turn, expressed their support for the Russian language in Ukraine (Kulyk 2014).

In this paper, I focus on the native languages/mother tongues in central Ukraine. Native language and mother tongue translate with ukr. ridna mova / russ. rodnoj jazyk. The adjective ridna / rodnoj can be translated as home or native (cf. ridne misto - home or native city), but also carries the meaning of related (by blood) (cf. ridnyj bat'ko - biological father), and of kinsfolk, kin, one's people / folk. Two questions will be addressed: 1) Which native languages are named by Ukrainians and how is this choice connected with the individual's first language(s)? 2) How are these native languages distributed regionally and socially? 


\section{Data}

In the present study I will analyse quantitative data stemming from a survey among 1,400 Ukrainians from central regions of Ukraine. This survey was carried out as part of a research project in June/July 2014, i.e. at a time after the "Euromaidan", the annexation of Crimea by the Russian Federation and during the escalation in eastern Ukraine. ${ }^{1}$ Some districts traditionally treated as belonging to the West (Xmel'nyc'kyj), the East (Xarkiv) and the South-East (Dnipropetrovs'k) were also included. Data collection was carried out in towns/cities and not in villages. In the latter, a still strong presence of dialects can be expected. The three cities with over one million residents, Kyjiv, Xarkiv and Dnipro (formerly Dnipropetrovs'k), were not taken into consideration. Figure 1 shows the location of the 56 towns/cities included in the survey.

Figure 1. The survey locations

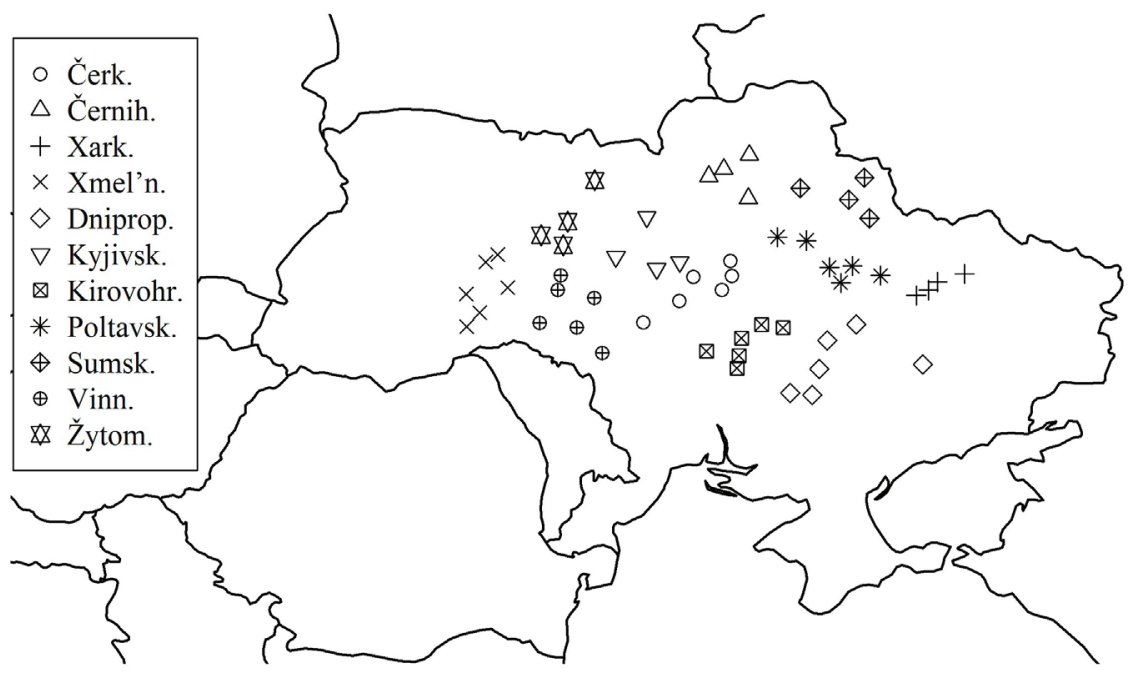

1 "Variability and stability in a mixed substandard in extensive and time-stable language contact: the Ukrainian-Russian mixed speech in Ukraine", funded by the Fritz Thyssen Foundation under the direction of Gerd Hentschel (University of Oldenburg) and Bernhard Kittel (University of Vienna). The project focused on the central regions of Ukraine, as these regions are where the URMS is most widespread. 
Among the respondents, 1,343 named Ukrainian as their "nationality". 57 stated a "Russian nationality". (During the Soviet Union, passports included citizens' nationality. In independent Ukraine, this is no longer the case.) Since the number of in this sense "Russian" respondents does not allow for deeper analyses, they are henceforth considered only marginally. Because of the negative connotation of the term "suržyk", and because of the vagueness of its denotation (laymen often understand it as any kind of non-standard speech, cf. Bilaniuk 2005) the expression "Ukrainian-Russian mixed speech" was used in the questionnaire.

\section{Native languages, first languages and used languages}

The language use in these central areas of Ukraine as assessed by the respondents has been described in Hentschel \& Tarenenko (2015) and in Hentschel \& Zeller (2017). All in all, Ukrainian predominates, but Russian and Ukrainian-Russian mixed speech are also in use everywhere. However, there are regional differences. As to the languages participants consider to be frequently used in their environment, the investigated districts can be divided into certain groups (Hentschel \& Taranenko 2015).

Table 1. The eleven districts according to the assessed use of the three codes. The percentages refer to respondents who regard the respective code as always or often used (average of three domains: use by the respondents themselves, in their families, in their environment).

\begin{tabular}{|l|c|c|c|c|c|c|c|}
\hline \multirow{2}{*}{ District } & \multicolumn{3}{|c|}{ Seen as always/often used by } & \multicolumn{3}{c|}{ Rank in the district } & \multirow{2}{*}{ Group } \\
\cline { 2 - 7 } & Ukr. & URMS & Russ. & Ukr. & URMS & Russ. & \\
\hline Xmel'n. & $95.0 \%$ & $36.3 \%$ & $10.4 \%$ & 1 & 2 & 3 & A \\
\hline Vinn. & $91.0 \%$ & $35.6 \%$ & $22.5 \%$ & 1 & 2 & 3 & $\mathrm{~A}$ \\
\hline Čerk. & $87.6 \%$ & $23.7 \%$ & $19.8 \%$ & 1 & 2 & 3 & $\mathrm{~A}$ \\
\hline Kyjiv & $92.8 \%$ & $63.6 \%$ & $35.7 \%$ & 1 & 2 & 3 & $\mathrm{~B}$ \\
\hline Čern. & $84.5 \%$ & $61.2 \%$ & $12.4 \%$ & 1 & 2 & 3 & $\mathrm{~B}$ \\
\hline Polt. & $78.6 \%$ & $57.6 \%$ & $36.7 \%$ & 1 & 2 & 3 & $\mathrm{C}$ \\
\hline Žytom. & $69.4 \%$ & $38.1 \%$ & $26.1 \%$ & 1 & 2 & 3 & $\mathrm{C}$ \\
\hline Kirov. & $67.8 \%$ & $44.3 \%$ & $41.3 \%$ & 1 & 2 & 3 & $\mathrm{C}$ \\
\hline Dniprop. & $66.2 \%$ & $85.7 \%$ & $31.4 \%$ & 2 & 1 & 3 & $\mathrm{D}$ \\
\hline
\end{tabular}


Table 1. The eleven... cd.

\begin{tabular}{|l|c|c|c|c|c|c|c|}
\hline \multirow{2}{*}{ District } & \multicolumn{2}{|c|}{ Seen as always/often used by } & \multicolumn{3}{c|}{ Rank in the district } & \multirow{2}{*}{ Group } \\
\cline { 2 - 7 } & Ukr. & URMS & Russ. & Ukr. & URMS & Russ. & \\
\hline Sumy & $57.1 \%$ & $88.1 \%$ & $37.4 \%$ & 2 & 1 & 3 & D \\
\hline Xark. & $27.9 \%$ & $45.3 \%$ & $69.4 \%$ & 3 & 2 & 1 & E \\
\hline
\end{tabular}

Source: reproduced from Hentschel \& Taranenko 2015.

The differences within the whole area under investigation have a gradual character, and they suggest not only the widely adopted east-west differentiation, but also a center-periphery differentiation. In the western and central districts of the area under investigation, Ukrainian is the dominant language, followed by URMS, and Russian in third place. This area can be divided further into three parts which differ in how clear this dominance of Ukrainian is. In the districts of Xmel'nyc'kyj, Vinnycja and Čerkasy (Group A), Ukrainian clearly dominates, the other codes play only a minor role. The districts of Kyjiv, Černihiv and Poltava (B) have similarly high values for Ukrainian, but also considerably high values for URMS as well. In Žytomyr and Kirovohrad (C), the figures for Ukrainian are lower, and the figures for URMS come closer to them. In only three districts is Ukrainian not the most often used language: in group (D), which includes the non-adjacent districts of Sumy in the north and Dnipropetrovs'k in the south, URMS is the most widespread code, followed by Ukrainian and Russian. Only in group (E), which consists only of the district of Xarkiv, Russian is dominant, and URMS takes second place (cf. also Hentschel \& Zeller 2017).

In order to see how these patterns of (assessed) real language use are connected with more symbolic aspects of linguistic affinity, I will begin with a general overview, adding the categories of first language and native language to the picture. Respondents were not only asked to indicate the language they used primarily in daily life and to indicate for every language on a five point-scale (never - rarely - sometimes - often - always) how often they use it. They also had to name one or several first languages (languages in which they started to speak). In addition, they had to choose their "main" native language, and they had the opportunity to mention one or more other native languages. Figure 2 shows the percentages of how many respondents 
named each language/code. In the case of the category "often used language", respondents who gave the answer "often" or "always" are counted. "Native language" includes both the answer "main native language" and the answer "other native language".

Figure 2. First, used and native languages, Ukrainian nationality $(n=1343)$

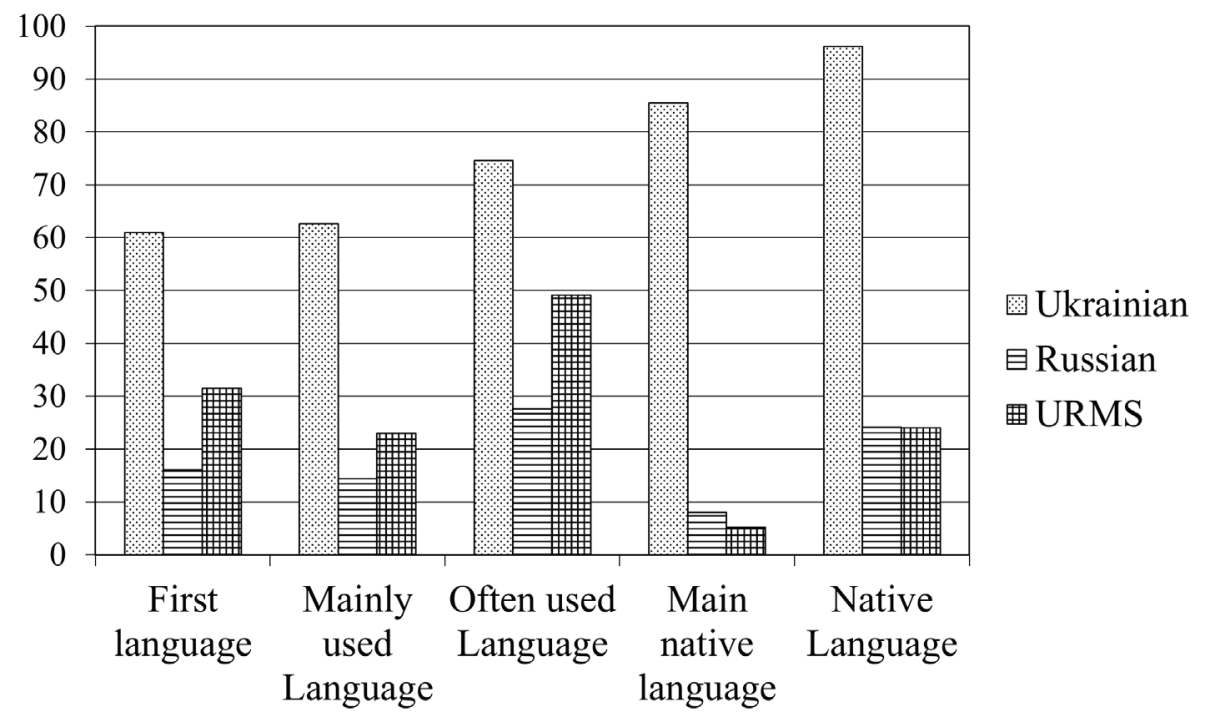

Ukrainian is by far the most widespread native language. Almost everybody mentions it as one of his/her native languages, and more than $80 \%$ as the main native language. Ukrainian is also the most frequently mentioned first language and mainly used language, but its dominance here is by far not that clear. This means that many people mention Ukrainian as one or even the main native language, although they did not learn it as their first one and although it is not their mainly used one. The case is the opposite for URMS: It is the second most widespread first language - every third respondent mentions it - and for every fourth respondent the mainly used language. The figures are lower for URMS as the main native language and also as native language in general. Many people do not call URMS their main, and some not even one out of several native languages, although naming it their first and mainly used language. Finally, Russian features only marginally as a first language. Even fewer people name it as their main native language. But contrary to 
URMS, Russian is more often named as one of the native languages than it is named as being among the first languages.

At this point a word about the interpretation of the two categories "main native language" and "native language" seems necessary. The latter is the more generous question. One could argue that it is the negative answer to such a question which is the marked one: A strong affiliation towards a language/code is not required to name this language as one native language among others. Consequently, not including a specific language as one native language among others would be a strong hint at a clear negative attitude towards the given language. Therefore, the proportions in this category can tell us something about a clear negative prestige of a language/code. As for the question of the main native language, the affirmative answer can be interpreted as the marked one. Naming a code as the main native language is a clear sign of a positive attitude, whereas not naming it as the main native language does not need to be connected with a negative attitude. In this sense, this category can tell us something about a particularly positive attitude towards a language/code.

From this, it follows that URMS has a clear negative overt prestige. People often reject that it is a native language to them. Russian, one might argue, has a rather neutral prestige. People do not call it their main native language very often, but they also do not reject that it is one of their native languages. Ukrainian clearly has the strongest positive identification potential as it is the native, and even the main native language, also for people who have not acquired it as a first language.

Before I come to this in some more detail below, let us have a look at the few respondents of Russian nationality. 
Figure 3. First, used and native languages, Russian nationality $(n=57)$

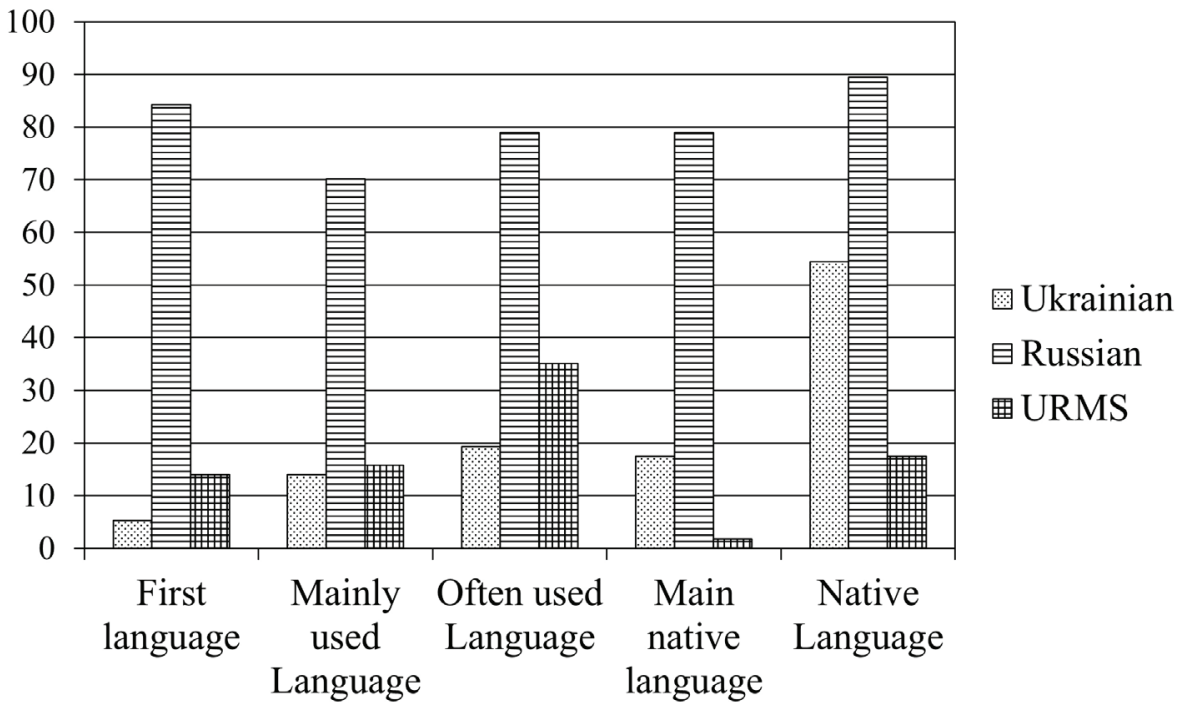

As mentioned above, the number of respondents with Russian nationality is too low to permit general conclusions and the results have to be interpreted with caution. The values seem at first sight to be diametrically opposed to people with Ukrainian nationality. Russian is the most widespread first, used and native language. However, this impression is relativized when the respondents' statement of their second native language is considered. More than half of them consider Ukrainian to be one of their native languages. This is particularly striking when one considers that virtually none of them mentioned Ukrainian as a first language. There is some identification with the Ukrainian language among Ukrainian citizens of Russian nationality, at least there is no strong rejection. 


\section{The relationship between the first and the native language}

In what follows I will examine the relationship between the first and the native language(s) in more detail. Figures 4 and 5 show the percentage values for the (main) native languages, differentiating between people who had the respective language as a first language and those who did not. These figures refer only to respondents with Ukrainian nationality.

Figure 4. Relationship between first and main native language (respondents of Ukrainian nationality, $n=1343$ ). (Without Ukrainian as first language: $n=525$, without Russian: $n=1127$, without URMS: $n=920$; with Ukrainian as a first language: $n=818$, with Russian: $n=216$, with URMS: $n=423$ )

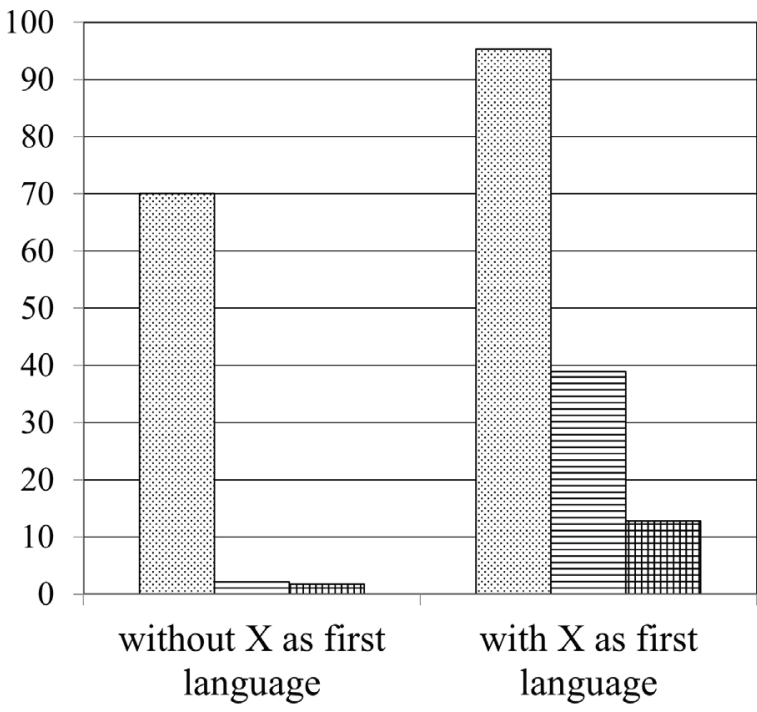

T. Ukrainian as main native language

目Russian as main native language

田URMS as main native language 
Figure 5. Relationship between first and native language (respondents of Ukrainian nationality, $n=1343$ ).

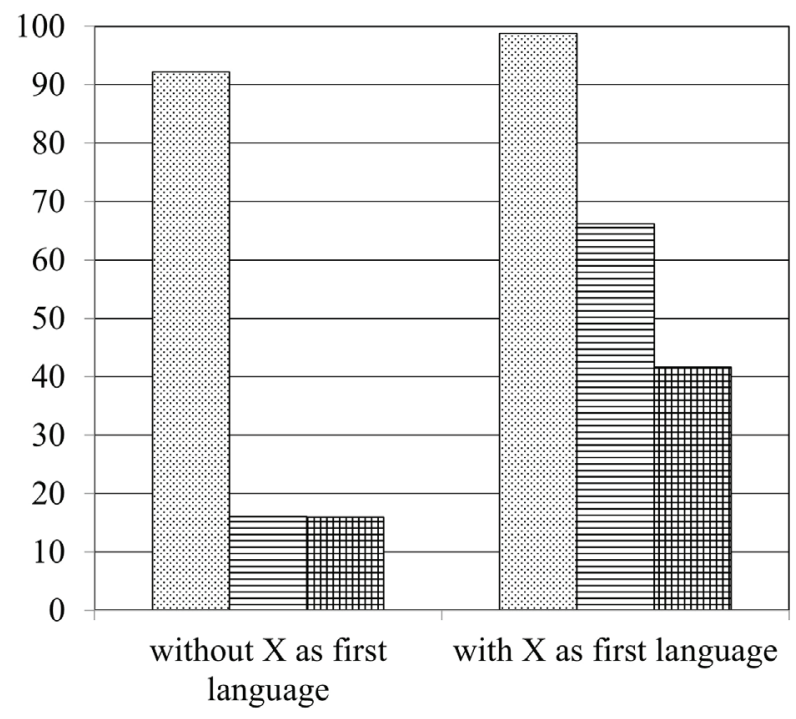

. native language

目Russian as one native language 囲URMS as one native language

Virtually all respondents who had Ukrainian as their first language name it as their main native language. For Russian, the figures are much lower. Only four out of ten who had Russian as their first language say that it is their main native language, and a third even denies that Russian is one of their native languages. This is even more extreme for URMS. Almost nine out of ten of those for whom it was the first language say that it is not their main native language, and six out of ten say that it is not their native language at all. Still, to put it positively, some people do see URMS as their native language, in spite of the overt stigma of this variety.

Without the respective language as first language the picture is even sharper. Practically all respondents name Ukrainian as one of their native languages, in spite of the fact that it was not their first language, and a high majority of 70 percent even name it as their main native language. Virtually nobody sees Russian or URMS as their main native language without having it as a first language. The figures are higher, but still low, when asking whether URMS or Russian are one of the respondents' native languages, and on a par for Russian and URMS. 
Summing up, there is a relation between the concepts of the first and the native language, but this relation is a) not a one-to-one correspondence and b) a different one for the three languages/codes. ${ }^{2}$ This is illustrated in Table 2 .

Table 2. Possible (in the sense of "observable") combinations of assignments of first and native languages in central Ukraine

\begin{tabular}{|c|c|c|c|}
\hline $\begin{array}{c}\text { First } \\
\text { Language }\end{array}$ & $\begin{array}{l}\text { Main native } \\
\text { language }\end{array}$ & $\begin{array}{l}\text { One native } \\
\text { language }\end{array}$ & $\begin{array}{c}\text { Combination } \\
\text { possible? }\end{array}$ \\
\hline$=$ Ukrainian & $=$ Ukrainian & & + \\
\hline$=$ Ukrainian & $\neq$ Ukrainian & $=$ Ukrainian & - \\
\hline$=$ Ukrainian & & $\neq$ Ukrainian & - \\
\hline$\neq$ Ukrainian & $=$ Ukrainian & & + \\
\hline \# Ukrainian & $\neq$ Ukrainian & $=$ Ukrainian & + \\
\hline$\neq$ Ukrainian & & $\neq$ Ukrainian & - \\
\hline$=$ Russian & $=$ Russian & & + \\
\hline$=$ Russian & $\neq$ Russian & $=$ Russian & + \\
\hline$=$ Russian & & $\neq$ Russian & + \\
\hline$\neq$ Russian & $=$ Russian & & - \\
\hline$\neq$ Russian & $\neq$ Russian & $=$ Russian & $(+)$ \\
\hline$\neq$ Russian & & $\neq$ Russian & + \\
\hline$=\mathrm{URMS}$ & $=\mathrm{URMS}$ & & $(+)$ \\
\hline$=\mathrm{URMS}$ & $\neq$ URMS & $=\mathrm{URMS}$ & + \\
\hline$=\mathrm{URMS}$ & & $\neq$ URMS & + \\
\hline$\neq \mathrm{URMS}$ & $=\mathrm{URMS}$ & & - \\
\hline$\neq$ URMS & $\neq \mathrm{URMS}$ & $=\mathrm{URMS}$ & $(+)$ \\
\hline$\neq$ URMS & & $\neq$ URMS & + \\
\hline
\end{tabular}

2 The situation is to some extent comparable to the situation in Belarus, with the important difference that Belarusian is much less used in Belarus compared to Ukrainian in Ukraine (Zeller \& Levikin 2016). 
All this argues for the importance of symbolic aspects in the choice of native language. People do not exclusively rely on observable, more or less objective facts when answering the question of their native language. In what follows, I will try to figure out which demographic factors influence the distribution of the native languages and therefore the symbolic dimension of linguistic affinity.

\section{The geographical and social distribution of the native languages}

The first factor that comes to mind for influencing language choices in Ukraine is the regional one. As mentioned above, the part of Ukraine under investigation is differentiated when it comes to the languages used predominantly. This, as well as the generally assumed different preferences in identities and attitudes, makes it likely that the symbolic dimensions of the three codes in question are not evenly distributed over the respective area.

I will analyse the influence of geography as well as the influence of other, social factors on the symbolic dimension of the three languages/codes by calculating Generalized Additive Mixed Models (GAMMs) in $R$ (R Core Team 2020), using the R-Package $m g c v$, version 1.8-33 (Wood 2011, 2017). This is a rather new method in sociolinguistic studies (see Wieling, Montemagni, Nerbonne, \& Baayen 2014) with two advantages. First, GAMMs make it possible to model non-linear relations. For example, it can be assumed that geography has an influence on the choice of the native language. But it is very plausible that this influence is non-linear, that is, that in reality we do not find a linear decline or rise in the probability of naming Ukrainian, Russian or URMS as one's native language from west to east and from north to south. The second advantage is that this method (like other mixed-effects regressions) allows for the control of random factors (as opposed to fixed factors like Age, Gender, Education etc., which are repeatable in other analyses and which include levels the researcher wants to compare). For example, it can be assumed that any town/city has an individual history which can make this location point different to the neighbouring ones and therefore would overlay the proper geographical influence. The method also allows for the control of random slopes. For example, one can control and test whether the influence of a certain fixed factor (like Age, Gender, Education etc.) is restricted to certain location points or whether it holds in general. 
The dependent variable of the following analyses is binary ( $\mathrm{x}$ is native language or not). The analyses model how the independent variables influence the probability that $\mathrm{x}$ is named as (main) native language. The following fixed factors will be tested: as a non-linear predictor Geographical Location, understood as an interaction of Longitude x Latitude, and as linear predictors Community Size (assessed from the Ukrainian Wikipedia in February 2015, log-transformed), the nationality of parents (Parents: is at least one of them of Russian nationality or not), Age, Gender and the level of Education: Higher (completed or incomplete), Professional, Secondary or Incomplete Secondary. The regression analyses will take only into account respondents stating Ukrainian as their nationality.

It would not be a surprise if there were an effect for Geographical Location considering all respondents. There are regional differences when it comes to both the used and the first languages and, as was shown above, there is a relationship between these concepts, albeit far from a one-to-one correspondence. In the following, the goal is to find out whether apart from these objective differences there are also regional differences in the symbolic dimension of the linguistic situation of Ukraine. I therefore restrict the analysis to a) persons without Ukrainian as first language in the case of the analysis of Ukrainian as main native language (since persons with Ukrainian as first language almost without exception name Ukrainian as their main native language); b) persons with Russian and URMS, respectively, as one of their first languages in the analyses of Russian and URMS as (main) native languages (since persons without these languages as their first ones almost never or at least very seldom name them as native language). Since the initial position is then the same for the sample, these analyses should show "pure symbolic" differences.

For reasons of space and to reduce the risk of accidentally getting significant results due to a high number of statistical models, not all combinations are tested. Because practically all respondents, including those for whom it was not the first one, consider Ukrainian to be one of their native languages, it seems more interesting to test which factors influence the choice of Ukrainian as the main native language, i.e. to look for a particularly positive attitude towards Ukrainian. In view of the generally rather neutral attitude towards Russian, I will look where there is a pronounced negative attitude towards Russian (i.e., where first-language speakers of Russian do not even 
name Russian as one native language among others). In view of the generally negative attitude towards URMS, I look where there is a pronounced positive attitude towards URMS (i.e., where first-language speakers of URMS name URMS as their main native language). Due to the in some cases low number of respondents, not only significant $(*: \mathrm{p}<0.05 ; * *: \mathrm{p}<0.01 ; * * *: \mathrm{p}<0.001)$, but also marginally significant factors $(+: p<0.1)$ are retained in the models.

\subsection{Choosing Ukrainian as the main native language}

Table 3 shows the model for Ukrainian as the main native language including all tested factors. Only persons without Ukrainian as a first language are taken into account. Fixed factors that are treated as linear predictors appear as "parametric coefficients" in the following tables. Fixed factors that are treated as non-linear predictors, random factors and random slopes appear as "smooth terms". 3

Table 3. Results of a GAMM regression modeling the probability of choosing Ukrainian as main native language for respondents without Ukrainian as first language

\begin{tabular}{|c|c|c|c|c|c|}
\hline $\begin{array}{l}\text { Parametric } \\
\text { Coefficients }\end{array}$ & Estimate & $\begin{array}{l}\text { Std. } \\
\text { Error }\end{array}$ & z-value & p-value & Significance \\
\hline (Intercept) & 2.13 & 1.74 & 1.23 & 0.220 & \\
\hline \multicolumn{6}{|l|}{$\begin{array}{l}\text { Education } \\
\text { (Reference: Higher) }\end{array}$} \\
\hline Professional & 0.24 & 0.29 & 0.83 & 0.410 & \\
\hline Secondary & 0.08 & 0.34 & 0.23 & 0.822 & \\
\hline Incomplete & -0.33 & 0.74 & -0.45 & 0.655 & \\
\hline Parents: Russian & -1.49 & 0.36 & -4.09 & $<0.001$ & $* * *$ \\
\hline Gender: Male & -0.41 & 0.23 & -1.78 & 0.075 & + \\
\hline Age & 0.00 & 0.01 & 0.40 & 0.688 & \\
\hline Community Size (Log) & -0.07 & 0.16 & -0.44 & 0.658 & \\
\hline
\end{tabular}

3 The following $\mathrm{R}$ command was applied: full_model $=$ gam(ukr_main_native $\sim$ education + parents + gender + age $+\log _{-}$community_size + s(longitude,latitude $)+\mathrm{s}($ town,bs="re") $+\mathrm{s}($ town, gender, bs="re") $+\mathrm{s}($ town, parents, bs="re"), data=ukr[temp,], family="binomial"). 
Table 3. Results... cd.

\begin{tabular}{|l|r|r|r|r|c|}
\hline \multirow{2}{*}{\multicolumn{1}{c|}{ Smooth Terms }} & \multicolumn{5}{|c|}{} \\
\cline { 2 - 6 } & edf & Ref.df & $\chi^{\mathbf{2}}$ & p-value & Significance \\
\hline $\mathrm{s}$ (Longitude, Latitude $)$ & 4.00 & 4.68 & 12.65 & 0.021 & $*$ \\
\hline $\mathrm{s}$ (Town) & 0.00 & 49.00 & 0.00 & 0.815 & \\
\hline $\mathrm{s}$ (Town, Gender $)$ & 0.00 & 94.00 & 0.00 & 0.607 & \\
\hline $\mathrm{s}$ (Town, Parents $)$ & 32.93 & 82.00 & 55.48 & $<0.001$ & $* * *$ \\
\hline
\end{tabular}

Education, Age and Community Size are not significant predictors for the choice of Ukrainian as the main native language. After excluding the non-significant fixed factors, as well as the non-significant random factor Town and the random slope for Gender per Town, the picture is as follows: Gender has a marginally significant influence: Male respondents name Ukrainian as their main native language somewhat less frequently than female respondents (Estimate $=-0.37 ; z=-1.66, p=0.097$ ). There is a clear influence of the parents' nationality. Respondents who have at least one parent of Russian nationality $(n=109)$ have in general a lower probability of choosing Ukrainian as their main native language than those without (Estimate $=-1.45, z=-4.24$, $p<0.001$ ). The effect of the parents' nationality varies per Town ( $e d f=30.41$, $\left.\operatorname{Ref} . d f=83.00, \chi^{2}=50.28, p<0.001\right)$. Finally, the probability of Ukrainian as the main native language varies by Geographical Location (edf $=4.05$, Ref. $d f=4.79, \chi^{2}=15.15, p=0.008$ ). Adjusted $R^{2}$ for the final model is 0.24 , with $n=506$. Figure 6 shows the effects of Geographical Location, Parents and Gender. 
Figure 6. Predicted probabilities of naming Ukrainian as the main native language. Only respondents without Ukrainian as a first language (Xm = Xmel'nyc'kyj, V = Vinnycja, $\breve{Z}=\breve{Z}$ ytomyr, $\mathrm{K}=$ Kyjiv, $\breve{\mathrm{C}}=$ = Černihiv, $\breve{C} \mathrm{k}=\breve{C}$ erkasy, $\mathrm{Kh}=$ Kirovohrad, $\mathrm{S}=$ Sumy, $\mathrm{D}=$ Dnipro, $\mathrm{Xa}=$ Xarkiv $)$
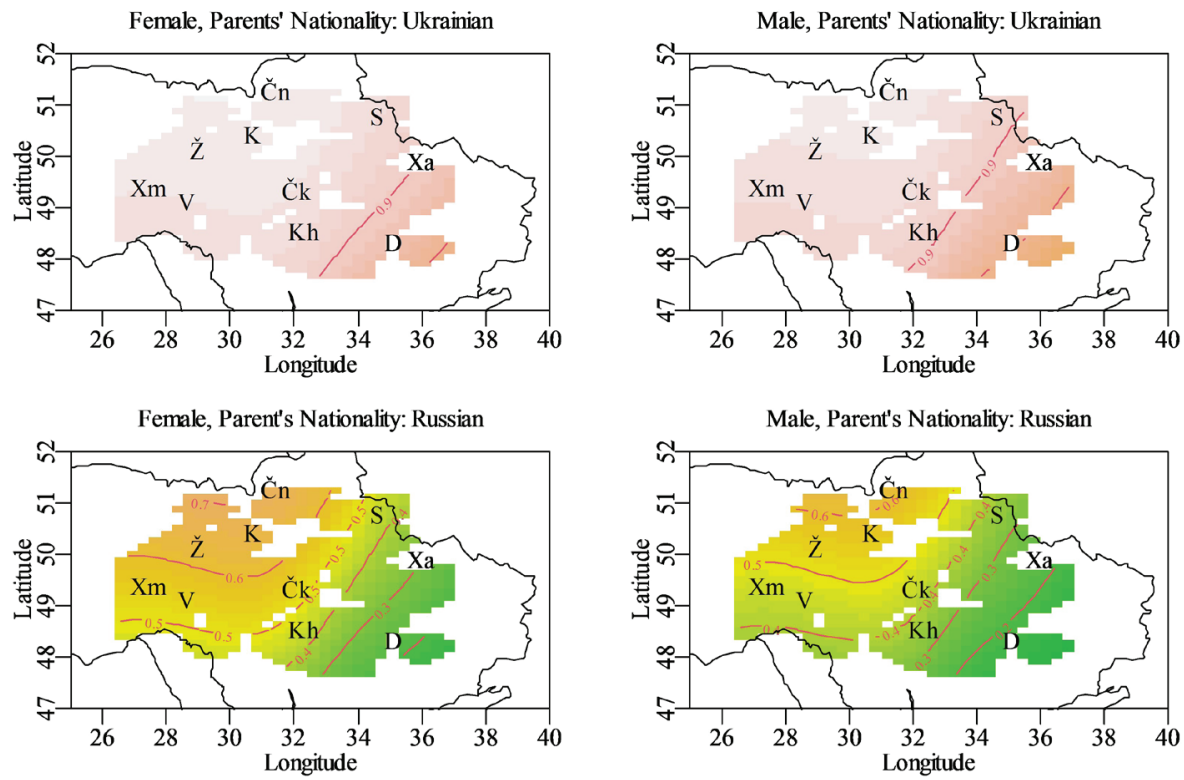

These maps show the probability of naming Ukrainian as the main native language across the surveyed region, comparing female with male respondents, and respondents with at least one parent of Russian nationality with respondents with parents of Ukrainian nationality only. They can be interpreted like a terrain map (see Wieling et al. 2014) with peaks and valleys, that is, with areas with a lower probability and with areas with a higher probability. Orange- and light-pink-coloured areas indicate a high probability of naming Ukrainian as the main native language, green a low, and yellow an intermediate probability. The lines can be understood as contour lines. Note that the city of Kyjiv itself was not included in the survey. White dots are missing values, that is, location points with no or too few observations. For those in the centre of the area under investigation, these are the regions along the Dnipro river. Note also that the model contains no information about the state borders, and therefore nearby Sumy extrapolates into the area of the Russian Federation. 
For respondents with only Ukrainian parents, the model predicts a probability of more than $90 \%$ of naming Ukrainian as the main native language in the largest part of the surveyed region. To the south-east, this probability slightly decreases, but is still higher than $80 \%$ in most parts, with only minor differences between male and female respondents. Again, it has to be kept in mind that these values refer to people without Ukrainian as first language. The regional differences are more pronounced for respondents with at least one Russian parent. For them, the model predicts a probability of more than $60 \%$ to $70 \%$ of naming Ukrainian as the main native language in the northwest, and under $20 \%$ to $30 \%$ in the south-east of the surveyed region.

\subsection{Choosing Russian as a native language}

In the analysis of Russian as a native language, only those persons are included who said that Russian was one of the first languages they used in their childhood. As was shown before, people without Russian as a first language only rarely name it as one of their native languages, (and virtually never name it as their main native language). Table 4 shows the results of a model including all tested factors.

Table 4. Results of a GAMM regression modeling the probability of choosing Russian as one native language for respondents with Russian as first language.

\begin{tabular}{|c|c|c|c|c|c|}
\hline \multirow{2}{*}{$\begin{array}{c}\text { Parametric } \\
\text { Coefficients }\end{array}$} & \multicolumn{5}{|c|}{} \\
\cline { 2 - 6 } & Estimate & Std.Error & z-value & p-value & Significance \\
\hline (Intercept) & 0.21 & 1.80 & 0.11 & 0.909 & \\
\hline $\begin{array}{l}\text { Education } \\
\text { (Reference: Higher) }\end{array}$ & & & & & \\
\hline Professional & 0.24 & 0.41 & 0.57 & 0.567 & \\
\hline Secondary & 0.21 & 0.47 & 0.45 & 0.656 & \\
\hline Incomplete & 41.46 & 67110000.00 & 0.00 & $>0.999$ & \\
\hline Parents: Russian & 1.12 & 0.39 & 2.88 & 0.004 & $* * *$ \\
\hline Gender: Male & -0.05 & 0.35 & -0.16 & 0.875 & \\
\hline Age & -0.03 & 0.02 & -1.86 & 0.063 & + \\
\hline Community Size (Log) & 0.12 & 0.15 & 0.80 & 0.423 & \\
\hline
\end{tabular}


Table 4. Results... cd.

\begin{tabular}{|l|c|c|c|c|c|}
\hline \multirow{2}{*}{\multicolumn{1}{c|}{$\begin{array}{c}\text { Smooth } \\
\text { Terms }\end{array}$}} & \multicolumn{5}{|c|}{} \\
\cline { 2 - 6 } & edf & Ref.df & $\chi^{\mathbf{2}}$ & p-value & Significance \\
\hline $\mathrm{s}($ Longitude, Latitude $)$ & 9.68 & 13.03 & 23.82 & 0.033 & $*$ \\
\hline $\mathrm{s}($ Town $)$ & 0.13 & 40.00 & 0.12 & 0.291 & \\
\hline $\mathrm{s}($ Town, Parents $)$ & 0.00 & 62.00 & 0.00 & 0.668 & \\
\hline
\end{tabular}

Due to the small number of cases, random slopes for the (marginally) significant factors had to be tested separately. There is no evidence that the influence of the factor Age is different in individual towns (s(Town, Age): $e d f=0.00$, Ref. $\left.d f=43.00, \chi^{2}=0.00, p=0.48\right)$.

Adjusted $R^{2}$ for the final model, that is, without non-significant factors, is 0.19 , with $n=208$. There is a significant effect for the nationality of parents (Estimate $=1.10, z=2.87, p=0.004)$. People with at least one Russian parent $(n=73)$ are more likely to call Russian one of their native languages. Older respondents have a slightly lower probability to call Russian their native language (a marginally significant effect: Estimate $=-0.03, z=-1.82, p=0.069$ ). Again, the probability is influenced by Geographical Location (edf $=9.90$, $\left.\operatorname{Ref} . d f=13.3, \chi^{2}=24.38, p=0.031\right)$. These effects are shown in Figure 7. 
Figure 7. Predicted probabilities of naming Russian as a native language.

Only respondents with Russian as a first language
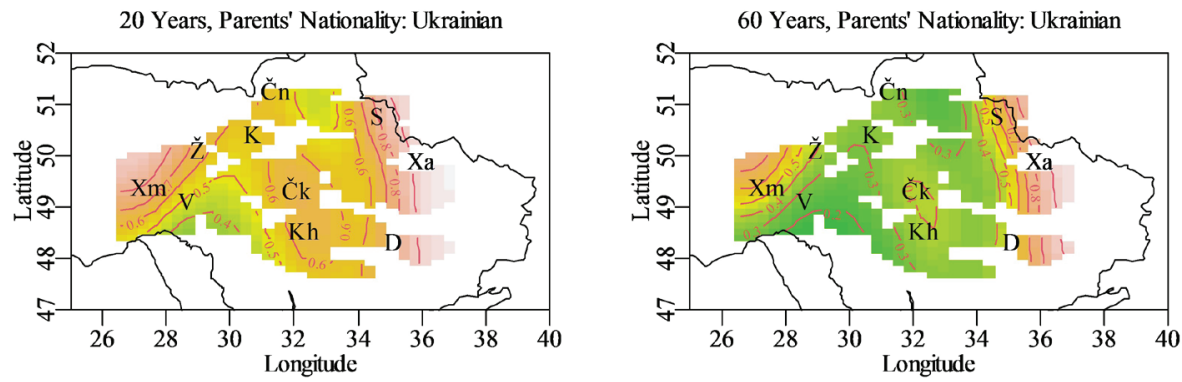

20 Years, Parent's Nationality: Russian

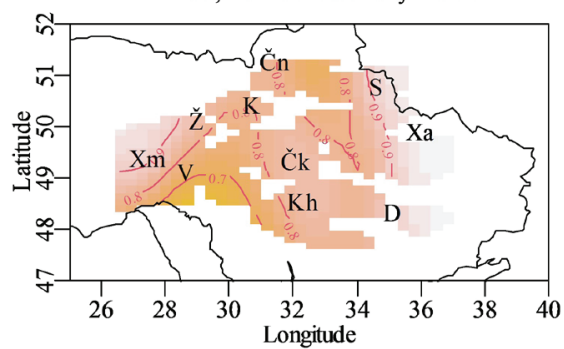

60 Years, Parent's Nationality: Russian

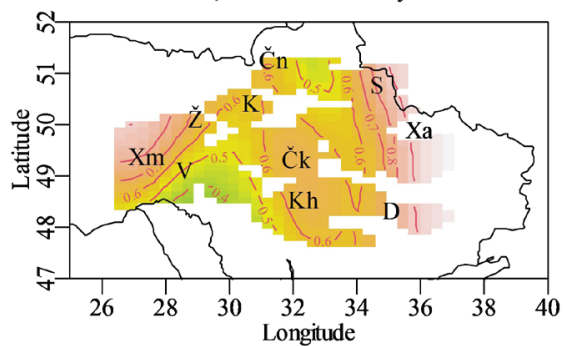

As already mentioned, the negative answers, i.e., the lower probabilities of naming Russian at least as one out of several native languages are the most telling ones. Not surprisingly, the least negative attitude towards Russian can be found around Xarkiv, where $70 \%$ of the respondents say that Russian is frequently used in their environment (Hentschel \& Taranenko 2015). From the furthest East, where the probability of naming Russian as a native language is higher than $80 \%$ to $90 \%$ for first-language speakers of Russian, there is a rather steep decline to the central parts, where the model predicts a probability of less than $50 \%$, partially less than $30 \%$, for respondents without parents of Russian nationality (but nota bene with Russian as a first language). Interestingly, the probability rises again in the western districts of Xmel'nyc'kyj and Žytomyr. The probability is higher for respondents with at least one parent of Russian nationality. 


\subsection{Choosing Ukrainian-Russian mixed speech as the main native language}

Table 5 shows the results of a model for the choice of URMS as the main native language including all tested factors. Only those respondents are included who said that UMRS was one of their first languages.

Table 5. Results of a GAMM regression modeling the probability of choosing URMS as main native language for respondents with URMS as first language.

\begin{tabular}{|c|c|c|c|c|c|}
\hline \multirow{2}{*}{$\begin{array}{l}\text { Parametric } \\
\text { Coefficients }\end{array}$} & \multirow[b]{2}{*}{ Estimate } & \multirow[b]{2}{*}{ Std.Error } & \multirow[b]{2}{*}{ z-value } & \multirow[b]{2}{*}{ p-value } & \multirow[b]{2}{*}{ Significance } \\
\hline & & & & & \\
\hline (Intercept) & -2.16 & 3.78 & -0.57 & 0.568 & \\
\hline \multicolumn{6}{|l|}{$\begin{array}{l}\text { Education (Reference: } \\
\text { Higher) }\end{array}$} \\
\hline Professional & -1.20 & 0.58 & -2.09 & 0.037 & $*$ \\
\hline Secondary & -0.45 & 0.60 & -0.74 & 0.458 & \\
\hline Incomplete & 0.64 & 0.98 & 0.66 & 0.512 & \\
\hline Parents: Russian & 0.11 & 0.56 & 0.19 & 0.847 & \\
\hline Gender: Male & 0.94 & 0.50 & 1.87 & 0.062 & + \\
\hline Age & 0.00 & 0.01 & -0.32 & 0.747 & \\
\hline Community Size (Log) & -0.05 & 0.36 & -0.14 & 0.887 & \\
\hline \multirow{2}{*}{$\begin{array}{c}\text { Smooth } \\
\text { Terms }\end{array}$} & & & & & \\
\hline & edf & Ref.df & $x_{2}$ & p-value & Significance \\
\hline $\mathrm{s}($ Longitude, Latitude) & 8.67 & 10.54 & 15.01 & 0.158 & \\
\hline $\mathrm{s}($ Town $)$ & 5.04 & 47.00 & 8.45 & 0.250 & \\
\hline $\mathrm{s}($ Town, Gender $)$ & 9.31 & 89.00 & 13.01 & 0.190 & \\
\hline $\mathrm{s}($ Town, Education $)$ & 11.19 & 124.00 & 16.31 & 0.063 & + \\
\hline
\end{tabular}

Excluding the non-significant random slope for Gender per Town, as well as the non-significant parametric coefficients results in a model with a significant interaction of Latitude and Longitude $(e d f=7.47$, Ref.df. $=9.34$, $\left.\chi^{2}=27.83, p=0.001\right)$. The probability of choosing URMS as main native language varies by the random factor Town $\left(e d f=5.51\right.$, Ref. $d f$. $=48.00, \chi^{2}=9.14$, $p=0.058$ ). The influence of Education varies per Town (edf $=9.77$, Ref.df. $\left.=129.00, \chi^{2}=13.44, p=0.059\right)$, but persons with professional 
education have in general a significantly lower probability of naming URMS as their main native language than persons with higher education (Estimate $=-1.10, z=-2.12, p=0.034)$. Respondents with incomplete secondary education have an even higher probability of choosing URMS as their main native language, but not significantly higher than persons with higher education (Estimate $=0.61, z=0.71, p=0.476$ ). These are very few respondents $(n=13)$, compared to those with higher $(n=95)$, professional $(n=205)$ and secondary education $(n=110)$. Male respondents name URMS more often as their main native language than female respondents (Estimate $=0.70$, $z=1.95, p=0.052$ ). $R^{2}$ for the final model is 0.30 , with $n=423$. The effect of Geographical Location, as well es the effects of Gender and of Education are shown in Figure 8.

Figure 8. Predicted probabilities of naming URMS as the main native language.

Only respondents with URMS as a first language
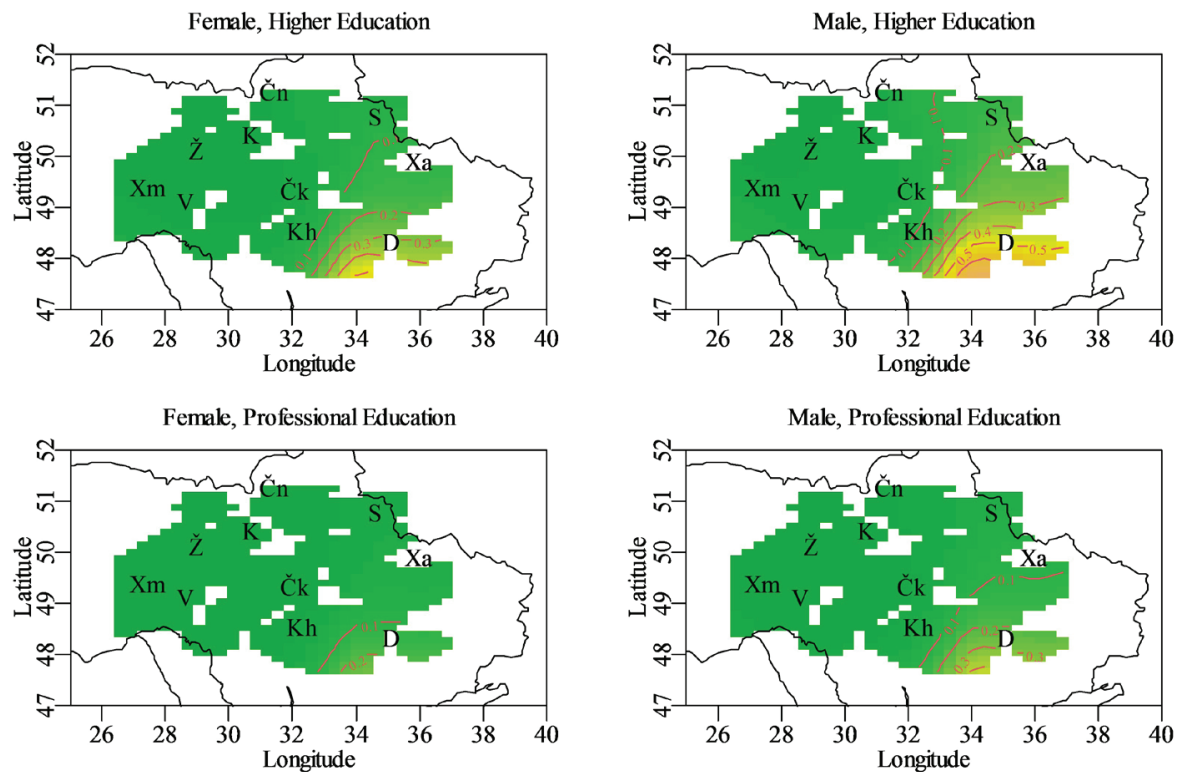

While there are two centres of URMS usage, i.e. around Sumy in the north and around Dnipropetrovs' $k$ in the south-east of the area under investigation (Hentschel \& Taranenko 2015), there is a clear difference between them when 
it comes to the acknowledgement of this code as the main native language. Only in the south-east, in the Dnipropetrovs'k district, are respondents with URMS as first language willing to call URMS their main native language, although the probability is still below $50 \%$ in most cases.

\section{Discussion}

On the basis of the percentage of respondents who named the three languages/codes under investigation as first, often and mainly used, and (main) native language, in section 3 and 4 the following preliminary interpretation of the symbolic linguistic situation in Ukraine was given: the strongest positive attitude is towards Ukrainian. It is named as native, and even main native language more often than it is named as first, and as mainly used language. Ukrainian-Russian mixed speech, the so-called Suržyk, has a clear negative overt prestige. People often deny that it is their native language, and very rarely see it as their main native language. Russian has a rather neutral prestige. People do not call it their main native language very often, but in most cases, they also do not reject that it is one of their native languages.

The analyses in section 5 investigated how these attitudes are distributed both regionally and to some degree socially in Ukrainian society. In the following I will discuss the results.

\subsection{The influence of social factors}

It is certainly no surprise that the nationality of the parents influences the choice of Russian as a native language and of Ukrainian as the main native language. Respondents with at least one parent of Russian nationality are less prone to call the Ukrainian language their main native language if it is not among their first languages. They are also less prone to an explicitly negative attitude towards Russian.

The gender of respondents correlates with the choice of Ukrainian as the main native language and with the choice of URMS as a native language, but the influence of Gender was in both cases only marginally significant and as can be seen from Figures 6 and 8 - not a strong one. Whereas women (without Ukrainian as first language) turned out to be somewhat more likely to call Ukrainian their main native language than men, men (with URMS as 
first language) are somewhat more likely to call URMS their native language than women. This is in line with various sociolinguistic studies which detect a higher affinity among women towards the standard language, a higher affinity among men towards non-standard varieties (e.g. Trudgill 1972). As for the self-reported language use in central Ukraine, there were no differences between men and women (Hentschel \& Zeller 2017). Women are slightly more often guided by the symbolic dimension of language. Such a tendency is sometimes explained by the argument that women's social position and status may be more dependent on community membership than men's (cf. Eckert 1998, Bilaniuk 2003). However, what is surprising is that it is the dichotomy Ukrainian - Suržyk which is affected here, while the choice of Russian is not affected. In the early 2000s, Bilaniuk (2003) found in a matched guise test that women were judged better when speaking Russian, whereas men were judged better speaking Ukrainian, so that women were "socially rewarded more for using Russian than for Ukrainian" (p. 74). It may be the case that this has changed in the course of Ukrainization over the last decades.

Interestingly, older respondents have a slightly lower probability to call their first language Russian also their native language (a marginally significant effect). One can only speculate about the reasons for this effect. Maybe it indicates that for some younger persons a "Ukrainian identity" is less in contradiction with an avowal of the Russian language.

The level of education only plays a role for URMS as the main native language. The pattern is interesting, and not straightforward to explain. An explicitly positive attitude towards URMS is most likely to be found among people (with URMS as a first language) with higher, or with incomplete education. It is seldom found among people with professional education (colleges, technical schools etc.). It is plausible that persons who for some reason or another did not attain the attempted education goal identify with a code with low overt prestige. As far as the respondents with a high level of education are concerned, the identification with URMS can speak for a covert prestige of the URMS, and for a more self-confident attitude towards the family past due to the level of education achieved. 


\subsection{The influence of geography}

The symbolic dimension of all three languages/codes varies in different regions of central Ukraine. The symbolic dimension of Ukrainian and URMS is additionally influenced by individual particularities of towns/cities. The population size of the location points does not seem to play a role.

A less enthusiastic attitude towards Ukrainian can be found in the southeast of the surveyed region, where fewer respondents who did not have Ukrainian as a first language call it their main native language. These are the areas, where Ukrainian is less likely to be used. But even there a majority clearly and strongly identifies with it.

Regional differences in the symbolic linguistic dimension that cannot be accounted for by differences in the amount of usage can be seen for URMS. Again, it is the South-East, that differs from the rest of the surveyed area. In the district of Dnipropetrovs'k, where at least some respondents identify with URMS as their main native language, URMS must have some positive prestige, in clear contrast to the district of Sumy where URMS is not seen as the main native language, although it is frequently used. At this point one can only speculate why this may be the case. A first guess is that the identification with the mixed substandard in Dnipropetrovs'k may be connected with an own identity model connected with the high industrialization of this district, a huge share of inhabitants who have not been living there for generations, and the traditional competition with the Russian-speaking industrial city of Donec'k.

The most puzzling case is the explicitly negative attitude towards Russian. Such an attitude can be seen in the central regions of the surveyed area, where many respondents who named Russian as their first language do not consider it to be their native language, not even their second besides Ukrainian. While it is plausible that in the mostly Russian-speaking east the attitude towards Russian is not negative, and that it is more negative in the centre, it is surprising that in the west of the investigated area it is also not explicitly negative. The - few - respondents with Russian as first language in the clearly Ukrainian-dominated West seem to differ from their fellow respondents in the centre in that they have a more self-confident attitude towards their first language. 


\section{Summary}

What do the results tell us 1) about the nature of the concept of "native language / mother tongue" and 2) about the linguistic situation in Ukraine? Ukrainians' choice of their native language first of all confirm that a person can declare to have, and therefore indeed have, more than one native language. The results stress the importance of symbolic aspects for the concept of native language. The choice of the native language is not completely independent from objective aspects such as the question whether a language was acquired during early childhood in the family, but this is not a one-to-one correspondence. Rather, at least in the case of Ukraine, we find different patterns of implicational relations. The presence of a language as first language can imply the choice of this language as the native language while the absence of this language as first language allows both options (this is the case for Ukrainian). Or the absence of a language as first language can imply that this language is not seen as native while the presence of this language as first language allows both options (this is the case for Russian and URMS).

All in all, the results indicate a high degree of identification with the Ukrainian language in central regions of Ukraine, and a negative attitude towards URMS in most areas, and also, in some areas, to Russian. Still, two aspects have to be stressed: First, there are dimensions of language attitudes that are not captured by the concept of native language / mother tongue. As was shown by Hentschel and Zeller (2016), with respect to the attitudes towards URMS respondents fall into four groups: 1) those who see URMS as a cultural threat and as useless in daily life, 2) those who do not see URMS as a cultural threat, but as useless in daily life, 3) those who do see URMS as a cultural threat, but also as useful in daily life, 4) and those who do not see URMS as a cultural threat, and as useful in daily life. That means, that URMS can be evaluated negatively on one dimension, but positively on the other.

Secondly, the symbolic value of Ukrainian, Russian, and URMS is not only geographically determined in the sense of an East-West or North-South pattern, but, as it seems, also on a more idiosyncratic local level. There are differences between towns and areas that cannot be explained by their geographical location, or by their population size, or, most notably, by the amount 
of actual use of the languages under question. These local differences call for further explanation.

\section{References}

Barner-Barry C., Hody C. A., 1995, The politics of change. The transformation of the former Soviet Union, New York: St. Martin's Press.

BILANIUK L., 2003, Gender, language attitudes, and language status in Ukraine. Language in Society 32, pp. 47-78, [online:] https://doi.org/10.1017/ S0047404503321037.

Bilaniuk L., 2005, Contested tongues. Language politics and cultural correction in Ukraine, Ithaca: Cornell University Press.

ECKERT P., 1998, Gender and sociolinguistic variation, in: J. Coates (ed.), Language and gender. A reader, Oxford and Malden, Mass.: Blackwell, pp. 64-75.

Engelman M., 2001, Language as metaphor. Linguistic ideology and the formation of Ukrainian and Jewish nationalism, Cambridge, Mass.: Harvard University Press.

Fournier A., 2002, Mapping identities: Russian resistance to linguistic Ukrainisation in Central and Eastern Ukraine, Europe-Asia Studies 54, pp. 415-433, [online:] https://doi.org/10.1080/09668130220129542.

Hentschel, G., 2018, Die weißrussische 'Trasjanka' und der ukrainische 'Suržyk' - grundlegende quantitativ-qualitative soziolinguistische Ähnlichkeiten und Unterschiede. in: S. Kempgen, M. Wingender, L. Udolph (eds.), Deutsche Beiträge zum 16. Internationalen Slavistenkongress Belgrad 2018, Wiesbaden: Harrassowitz, pp. 127-138.

Hentschel G., BRÜGGEMANN M., 2015, Gibt es in der Ukraine einen ukrainisch-russischen Sprachenkonflikt? Über das Miteinander, Gegeneinander und Durcheinander von Ukrainisch und Russisch, in: E. Bakalova, T. Endrich, Kh. Shlyakhtovska (eds.), Ukraine. Krisen. Perspektiven, Berlin: Wissenschaftlicher Verlag Berlin, pp. 95-118.

Hentschel G., Taranenko O., 2015, Die Sprachenlandschaft der zentralen Ukraine: Ukrainisch, Russisch, 'Suržyk'. Verwendung - Kompetenz - nationale Positionierung, Die Welt der Slaven LX, pp. 248-275.

Hentschel G., Zeller J. P., 2016, Meinungen und Einstellungen zu Sprachen und Kodes in zentralen Regionen der Ukraine, Zeitschrift für Slawistik 61, pp. 636-661, [online:] https://doi.org/10.1515/slaw-2016-0039.

Hentschel G., Zeller J. P., 2017, Aspekte der Sprachverwendung in zentralen Regionen der Ukraine, Wiener Slawistischer Almanach 79, pp. 37-60.

KapPeler A., 2011, Die Ukraine: Prozesse der Nationsbildung, Köln: Böhlau. 
Korostelina K. V., 2013, Identity and power in Ukraine, Journal of Eurasian Studies 4, pp. 34-46, [online:] https://doi.org/10.1016/j.euras.2012.10.002.

KulyK V., 2010, Languages and language ideologies in Ukraine, Berlin: Mouton de Gruyter.

Kulyk V., 2014, Einheit und Identität. Sprachenpolitik nach dem Majdan, Osteuropa 64, pp. 227-237.

KulyK V., 2016, Language and identity in Ukraine after Euromaidan, Thesis Eleven 136, pp. 90-106, [online:] https://doi.org/10.1177/0725513616668621.

KuzIo T., 2002, The nation-building project in Ukraine and identity. Toward a consensus, w: T. Kuzio, P. D’Anieri (eds.), Dilemmas of state-led nation building in Ukraine, Westport, Conn.: Praeger, pp. 9-28.

Masenko L., 2020, Language conflict in Ukraine: Finding of settlement, in: D. Müller, M. Wingender (eds.), Discourse and practice of bilingualism. Contemporary Ukraine and Russia/Tatarstan, Wiesbaden: Harrassowitz, pp. 31-42.

Moser M., 2013, Language policy and discourse on languages in Ukraine under President Viktor Yanukovych (25 February 2010 - 28 October 2012), Stuttgart: ibidem.

Moser M., 2015, Pushing the "regional language"_-Ukraine's law "On principles of the state language policy" in force, in: G. E. Brogi, M. Dyczok, O. Pachlovska, G. Siedina (eds.), Ukraine twenty years after independence: Assessments, perspectives, challenges, Roma: Aracne editrice, pp. 189-211.

O’Rourke B., Ramallo F., 2011, The native - non-native dichotomy in minority language contexts. Comparisons between Irish and Galician, Language Problems \& Language Planning 35, pp. 139-159, [online:] https://oi.org/10.1075/ lplp.35.2.03oro.

Osipian A. L., Osipian A. L., 2012, Regional diversity and divided memories in Ukraine: contested past as electoral resource 2004-2010, East European Politics \& Societies 26, pp. 616-642, [online:] https://doi.org/10.1177/0888325412447642.

Pop-Eleches G., Robertson G. B., 2018, Identity and political preferences in Ukraine - before and after the Euromaidan, Post-Soviet Affairs 34, pp. 107-118, [online:] https://doi.org/10.1080/1060586X.2018.1452181.

R Core Team, 2020, $R$ : A language and environment for statistical computing, R Foundation for Statistical Computing, Vienna, Austria, [online:] https://www.R-project.org/, [06.06.2021].

RAmpton M. B. H., 1990, Displacing the 'native speaker'. Expertise, affiliation, and inheritance, ELT Journal 44, pp. 97-101, [online:] https://oi.org/10.1093/ eltj/44.2.97.

Riabchuk M., 2002, Ukraine: One State, Two Countries? Tr@nsit online 23/2002, [online:] http://www.iwm.at/read-listen-watch/transit-online/ukraine-one-state-two-countries/, [11.05.2016]. 
Riabchuk M., 2015, 'Two Ukraines’ Reconsidered: The End of Ukrainian Ambivalence? Studies in Ethnicity and Nationalism 15, pp. 138-156, [online:] https://doi. org/10.1111/sena.12120.

Shulman St., 2004, The contours of civic and ethnic national identification in Ukraine, Europe-Asia Studies 56, pp. 35-56, [online:] https://doi.org/10.1080/0966813 032000161437.

Singh R., 2006, Native speaker, in: K. Brown (ed.), Encyclopaedia of Language and Linguistics, London: Elsevier, pp. 489-492.

Skutnabb-Kangas T., Phillipson R., 1989, 'Mother tongue': The theoretical and sociopolitical construction of a concept, in: U. Ammon (ed.), Status and function of languages and language varieties, Berlin \& New York: Mouton de Gruyter, pp. $450-477$.

TÖRnQuist-Plewa B., 2006, History, language and society in the borderlands of Europe. Ukraine and Belarus in focus, Malmö: Sekel.

Trudgill P., 1972, Sex, covert prestige and linguistic change in the urban British English of Norwich, Language in Society 1, pp. 179-195, [online:] https://doi. org/10.1017/S0047404500000488.

Wieling M., Montemagni S., Nerbonne J., BaAyen R. H., 2014, Lexical differences between Tuscan dialects and standard Italian: Accounting for geographic and socio-demographic variation using generalized additive mixed modeling, Language 90, pp. 669-692.

Wilson A., 2009, The Ukrainians. Unexpected nation, New Haven: Yale University Press.

Wood S. N., 2011, Fast stable restricted maximum likelihood and marginal likelihood estimation of semiparametric generalized linear models, Journal of the Royal Statistical Society (B) 73, pp. 3-36, [online:] https://doi.org/10.1111/j.1467-9868.2010.00749.x.

Wood S.N., 2017, Generalized additive models. An introduction with $R$, 2nd edition, Boca Raton: CRC.

ZALIZNIAK H., 2020, Language situation change in Ukraine as a result of the revolutionary events of 2013-2014 (Findings from a mass survey), in: D. Müller, M. Wingender (eds.), Discourse and practice of bilingualism. Contemporary Ukraine and Russia/Tatarstan, Wiesbaden: Harrassowitz, pp. 71-88.

ZALIZnJAK H., 2012, Problemy nacional'noji identyfikaciji rosijs'komovnych hromadjan v Ukrajini, in: B. M. Ažnjuk (ed.), Ekolohija movy i movna polityka v sučasnomu suspil'stvi, Kyjiv: D. Buraho, pp. 249-254.

Zeller J. P., forthcoming, Linguistic, political, and cultural attitudes and identities in central Ukraine in 2014, to appear in: D. Müller, M. Wingender (eds.), Languages in conflict situations - Russia and Ukraine, Wiesbaden: Harrassowitz. 
Zeller J. P., Levikin, D., 2016, Die Muttersprachen junger Weißrussen. Ihr symbolischer Gehalt und ihr Zusammenhang mit sozialen Faktoren und dem Sprachgebrauch in der Familie, Wiener Slavistisches Jahrbuch (Neue Folge) 4, pp. 114-144.

\section{Rozmieszczenie geograficzne i społeczne języków ojczystych w środkowej Ukrainie \\ (streszczenie)}

Deklarując dany język jako swój język natywny/rodzimy lub język ojczysty, ludzie dokonują aktu identyfikacji z tym językiem, a poprzez ten język z ludźmi i ideami, którym przypisują ten sam język. Wysuwa się to na pierwszy plan zwłaszcza wtedy, gdy konflikty zewnętrzne przenoszą się na zróżnicowanie języków. Tak jest na Ukrainie, gdzie do dyspozycji są trzy języki/kody: państwowy język urzędowy ukraiński, ale także rosyjski oraz ,surżyk”, powszechna forma mowy zawierająca zarówno elementy ukraińskie, jak i rosyjskie. W oparciu o ankietę z 2014 r. przeprowadzoną $\mathrm{w}$ centralnych regionach Ukrainy, w niniejszym artykule zbadano, który z tych języków/kodów został wybrany jako język ojczysty i jak ten wybór jest powiązany z bardziej obiektywnymi aspektami używania języka. Za pomocą generatywnego addytywnego modelu mieszanego zostanie przedstawione, jak ten wybór jest zróżnicowany zarówno społecznie, jak i geograficznie.

S łow a k lu c ze : ukraiński; rosyjski; surżyk; język natywny/rodzimy; język ojczysty; język i społeczeństwo; symboliczne aspekty języka; wielojęzyczność; postawy językowe 